\title{
Analisis Kebijakan Prinsip Governance dan Aktor Melalui Analytical Hierarchy Process (AHP) dalam Perencanaan Kota
}

\author{
An Analysis on Governance Principle Policy and Actor using Analytical Hierarchy Process \\ $(A H P)$ in City Planning
}

\author{
Bambang Utoyo $\mathrm{S}$ \\ Ilmu Administrasi Negara FISIP Universitas Lampung \\ bambang6263@gmail.com
}

\begin{abstract}
Abstrak
Perencanaan tata ruang kota sebagai bagian dari kegiatan perencanaan tata ruang sebenarnya adalah bentuk rumusan kebijakan publik yang berkaitan dengan pengelolaan ruang kota. Langkah yang diambil oleh pelaku kebijakan dalam proses perumusan kebijakan publik akan sangat ditentukan oleh perspektif yang digunakan. Tata kelola sebagai perspektif utama dalam administrasi publik dan manajemen menuntut penerapan prinsip-prinsip yang dikaitkan dengannya untuk mencapai pemerintahan yang baik. Menimbang ini, masalah penelitiannya adalah: bagaimana prioritas prinsip tata kelola yang terkait dengan aktor/agen yang terlibat dalam perencanaan kota? Tujuan penelitian adalah untuk mengetahui, mendeskripsikan, dan menganalisis prioritas prinsip tata kelola yang berkaitan dengan aktor/agen yang terlibat dalam perencanaan kota. Penelitian ini pada dasarnya merupakan penelitian deskriptif dengan menggunakan analisis model kuantitatif, yaitu Analytical Hierarchy Process. Sumber data diambil dari responden penelitian yang terdiri dari unsur pemerintah kota; Sektor masyarakat sipil dan swasta (bisnis). Hasil penelitian menunjukkan bahwa prioritas penerapan prinsip tata kelola dalam perencanaan kota berdasarkan pelaku/agen yang terlibat adalah: pertama: partisipasi (3,141); kedua: responsif (3.021); ketiga: transparansi (3.009); dan keempat: akuntabilitas (2.867), dengan nilai aktor: masyarakat sipil (1.168); pemerintah kota (1.096); dan bisnis (swasta) dengan nilai masing-masing (0,736). Partisipasi masyarakat madani dilakukan di seluruh tahapan perencanaan kota dalam bentuk penyediaan data dan informasi, pendapat dan aspirasi, serta keberatan dan bantahan terhadap konsep pembangunan teritorial kota. Sementara itu, secara praktis, penelitian tersebut merekomendasikan perlunya peraturan tentang partisipasi masyarakat sipil dalam perencanaan kota di alam untuk menemukan praktik terbaik; Penerapan prinsip tata kelola harus menjadi pola pikir petugas publik dan perencana dalam perencanaan tata ruang.
\end{abstract}

\section{Kata kunci: Perencanaan kota; Pemerintahan dan aktor}

\begin{abstract}
Urban spatial planning as a part of spatial planning activities actually is a form of public policy formulation related with urban space management. Actions done by the policy actor in the formulation process of public policy will be extremely determined by the perspectives used. Governance as the main perspective in public administration and management demands
\end{abstract}


the application of principles which attributed to it in order to achieve good governance. Based on that, the problem of the research is: how is the priority of the governance principles related to the actor/agent involved in urban planning? The purposes of the research are to know, to describe, and to analyze the priority of governance principles related to the actor/agent involved in urban planning. The type of the research, basically, is a descriptive research using the quantitative model analysis, that is Analythical Hierarchy Process. Data sources are taken from the research respondents which are consisting of municipal government elements; civil society and private (business) sector.

The result shows that the priorities of governance principles application in urban planning based on the involved actor/agent are: first: participation (3.141); second: responsive (3.021); third : transparancy (3.009); and fourth : accountability (2.867), with the actors value: civil society (1.168); municipal government (1.096); and business (private) sector by the value of (0.736) respectively. Civil society participation is done to the whole phases of urban planning in the form of providing data and information, opinion and aspiration, as well as objection and rebuttal toward the concept of city territorial development. Meanwhile, practically, the research recommends the need of regulation toward the civil society participation in urban planning in local nature to find the best practice; the application of governance principles should become the mindset of public officer and the planner in spatial planning.

Key word: Urban planning; governance and actor

\section{Pendahuluan}

Wilayah perkotaan dewasa ini telah menunjukan perkembangan yang sangat pesat sejalan dengan pembangunan di Indonesia pada umumnya. Hal ini tidak terlepas dari kenyataan bahwa perkotaan adalah lokasi yang paling effisien dan effektif untuk kegiatan-kegitan produktif sehubungan dengan ketersediaan sarana dan prasarana, tersedianya tenaga trampil, tersedianya dana sebagai modal dan sebagainya (Anwar, 1994). Tidak berlebihan kalau dikatakan bahwa perkotaan memiliki nilai strategis.

Perkotaan tidak sekedar sebagai pemusatan penduduk serta berbagai fungsi sosialekonomi-politik dan administrasi, tetapi juga potensial sebagai instrumen untuk mencapai tujuan-tujuan pembangunan pada tingkat lokal, regional maupun nasional.

Sebagai kawasan yang relatif lebih lengkap prasarana dan sarananya, kota telah menimbulkan daya tarik yang sangat besar bagi terjadinya arus perpindahan penduduk dari perdesaan ke perkotaan. Peningkatan jumlah penduduk tersebut, juga disertai dampak ikutan yang sulit dikesampingkan terutama dalam hal keterbatasan ketersediaan dan kemampuan pelayanan infrastruktur penunjang aktivitas masyarakat kota. Dengan demikian manajemen pembangunan kawasan perkotaan perlu disesuaikan sejalan dengan dinamisasi serta perubahan pada tataran empiris maupun perkembangan pemikiran dalam administrasi publik.

Maka dari itu, manajemen perkotaan perlu dimantapkan kembali agar penanganan 
kawasan perkotaan di masa depan lebih efektif. Hal yang sangat penting dan krusial dalam manajemen pembangunan perkotaan adalah pada tahap proses perencanaan, sebab tanpa adanya perencanaan mustahil segala yang dicitacitakan dapat terwujud. Oleh Y. Dror seperti dikutip oleh Kunarjo (1994), perencanaan dimaknai sebagai suatu proses penyiapan seperangkat keputusan untuk dilaksanakan pada waktu yang akan datang yang diarahkan pada pencapaian sasaran tertentu. Demikian pula Conyers dan Hills dalam Riyadi (2003), juga mengemukakan bahwa "planning is a continuous process which involves decisions, or choice, about alternatif ways of using available resources, with the aim of achieving particulars goals at sometimes in the future". Dalam kaitannya dengan manajemen perkotaan, ketersediaan Rencana Tata Ruang Wilayah Kota (RTRWK) yang merupakan output dari perencanaan tata ruang adalah prasyarat utama bagi penyelenggaraan pembangunan kota, mengingat RTRWK menjadi acuan dasar didalam penyelenggaraan pembangunan setiap sektor pengisi ruang kota tersebut (Dardak, 2006). Rencana tata ruang kota yang baik perlu disusun dengan melibatkan semua stakeholders, baik pemerintah, masyarakat, dan swasta, melalui mekanisme tertentu yang memungkinkan semuanya dapat terlibat secara aktif (Syarif, 2005).

Oleh karena itu, perencanaan tata ruang sebagai salah satu bagian dalam aktivitas penataan ruang sesungguhnya merupakan bentuk formulasi kebijakan publik yang terkait dengan dengan pengelolaan ruang kota. Dalam sebuah proses perencanaan, akan sangat terkait sekali dengan proses penentuan pilihan-pilihan yang merupakan pengejawentahan dari proses politik yang terjadi dalam proses perumusan kebijakan publik. Sehingga setiap aktivitas yang ada di dalamnya merupakan sebuah usaha yang dilakukan memiliki titik fokus untuk mencapai sebuah kondisi keruangan dalam konteks problem solving, future oriented dan resource allocation. Friedman (1987), mencoba memberikan definisi lebih luas mengenai planning sebagai upaya menjembatani pengetahuan ilmiah dan teknik (scientific and technical knowldge) kepada tindakan-tindakan dalam domain publik, menyangkut proses pengarahan sosial dan proses transformasi sosial. Dengan demikian, bahwa keterlibatan stakeholder dalam perencanaan mengalami pergeseran, dari for people sebagai sifat perencanaan social reform menjadi by people sebagai sifat perencanaan dalam social learning.

Dalam kerangka perencanaan dipandang sebagai sebuah alat dan metode dalam pengambilan keputusan dan tindakan publik, maka sudah sewajarnya dipahami akan adanya dimensi politik dalam perencanaan. Tindakan-tindakan yang dilakukan oleh pelaku kebijakan dalam proses perumusan kebijakan publik akan sangat ditentukan oleh perspektif yang digunakan. Teori atau perspektif governance sebagai perspektif utama dalam khasanah administrasi dan manajemen publik sesungguhnya merupakan mekanisme pengelolaan sumber daya ekonomi dan sosial yang melibatkan pengaruh sector negara/ pemerintah dan sector non-pemerintah dalam suatu usaha kolektif (Pratikno, 2005). Pemahaman tersebut mengasumsikan banyak aktor yang terlibat 
dimana tidak ada yang sangat dominan yang menentukan gerak aktor lain. Pesan pertama dari terminologi governance membantah pemahaman formal tentang bekerjanya institusi-institusi negara. Governance mengakui bahwa didalam masyarakat terdapat banyak pusat pengambilan keputusan yang bekerja pada tingkat yang berbeda. Dengan demikian, terjadi perubahan dari peran pemerintah dari government ke governance, ketika seluruh pihak terkait dianggap sebagai bagian dari penyelenggaraan pengelolaan kota (Prijadi, 2001)

Oleh karena itu, dalam penyusunan rencana tata ruang wilayah, tuntutan penerapan prinsip-prinsip good governance hendaknya terus diupayakan melalui peningkatan kepedulian dan peran masyarakat khususnya dalam penetapan fungsi, peran, serta pendekatan kebijakan dan strategi penataan ruang. Pada level terendah, penerapan prinsip-prinsip good governance ini dilakukan melalui pelibatan masyarakat dalam pengelolaan lingkungan di sekitar tempat tinggalnya (Purnomohadi, 2006).

Hal tersebut menjadi sangat penting, mengingat arah baru administrasi publik dalam dekade sekarang ini cenderung lebih mengedepankan konsep good governance dalam mengelola berbagai kepentingan dan urusan publik melalui berbagai keputusan publik dengan melibatkan lebih banyak petaruh di luar aktor negara atau pemerintah. Transformasi yang cukup signifikan dalam perkembangan administrasi publik adalah adanya kebutuhan untuk melakukan redifinisi pola hubungan antara pemerintah; masyarakat dan sektor swasta. Oleh karenanya tantangan yang dihadapi oleh administrasi publik dewasa ini relatif jauh lebih berat dibandingkan dengan masa-masa sebelumnya. Sungguhpun demikian, yang paling penting adalah bagaimana perubahan ini membawa ke arah terwujudnya arah baru administrasi publik menuju konsep good governance (lihat: Bovair, 2003; dan Hans Klijn and Koppenjan, 2012)

Seiring dengan perkembangan paradigma dalam administrasi publik yang dibarengi dengan menguatnya tuntutan terhadap demokratisasi dan desentralisasi, penelitian ini berusaha mengkaji penerapan governance, khususnya dalam implementasi nilai dan prinsip-prinsipnya dalam aktivitas perencanaan tata ruang kota. Proses pengambilan keputusan publik secara demokratis melalui pendekatan governance dalam kerangka desentralisasi merupakan suatu proses yang sangat kondusif terhadap konsep perencanaan (tata ruang) sebagai sebuah proses pembelajaran sosial, dimana peran masyarakat (termasuk di dalamnya civil society dan privat sektor) sebagai stakeholder menjadi sangat diperhatikan dibandingkan dengan proses pengambilan keputusan yang dilakukan pada pola rasional semata.

Penelitian ini mempunyai tujuan untuk mengetahui, mendeskripsikan dan menganalisis prioritas prinsip governance terkait dengan aktor/ agensi yang terlibat dalam perencanaan tata ruang wilayah kota, khususnya di Kota Metro Propinsi Lampung. 


\section{Metode Penelitian}

Penelitian ini pada dasarnya adalah Penelitian Deskriptif dengan menggunakan model analisis kuantitatif. Variabel utamanya adalah perencanaan kota, yang terkait dengan penerapan prinsip governance dan aktor/ agensi yang terlibat dalam penyusunannya. Data dalam penelitian ini dihimpun melalui metode survai terhadap aktor yang terlibat dalam penyusunan perencanaan kota, yaitu aktor pemerintah kota; unsur masyarakat (civil society) dan sektor swasta (bisnis) yang ditentukan secara purposive yang memiliki kompetensi dan pengetahuan yang cukup terhadap perencanaan kota.

Model analisis yang digunakan untuk mengkaji prioritas prinsip governance terkait dengan aktor/ agensi yang terlibat dalam perencanaan tata ruang wilayah kota menggunakan model analisis proses hirarki. Analisis Proses Hiraraki (AHP) adalah prosedur yang berbasis matematis yang sangat baik dan sesuai untuk kondisi evaluasi atribut-atribut kualitatif (Saaty, 1990). Atribut-atribut tersebut secara matematik dikuantitatifkan dalam satu set perbandingan berpasangan. Karena menggunakan input persepsi manusia, model ini dapat mengolah data yang bersifat kualitatif maupun kuantitatif. Selain itu, AHP mempunyai kemampuan untuk memecahkan masalah yang multi obyektif dan multi kriteria yang didasarkan pada perbandingan preferensi dari setiap elemen dalam hirarki. Hirarki adalah abstraksi struktur suatu sistem yang mempelajari fungsi interaksi antara komponen dan juga dampak-dampaknya pada sistem. Struktur hirarki dalam penelitian digambarkan seperti diagram berikut ini.

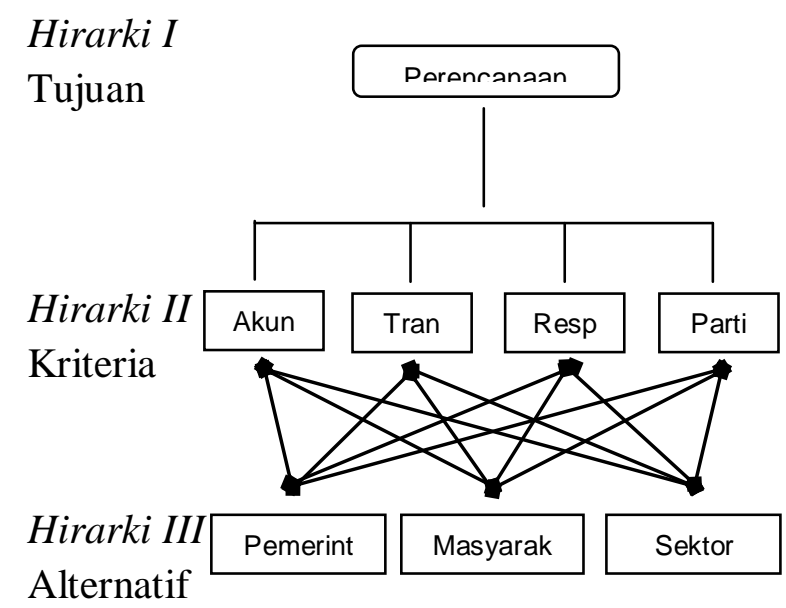

Gambar 1. Stuktur Hirarki Untuk Pendekatan Governance dalam

Perencanaan Tata Ruang Kota

\section{Hasil dan Pembahasan}

Dokumen Rencana Tata Ruang Wilayah (RTRW) sebagai produk dari perencanaan tata ruang, pada hakekatnya merupakan suatu paket kebijakan umum pengembangan daerah. Rencana tata ruang merupakan hasil perencanaan wujud struktural dan pola pemanfaatan ruang. Bagi wilayah Kota Metro, kebijakan yang dirumuskan pada dokumen ini merupakan dasar strategi pembangunan spasial, baik yang berkenaan dengan perencanaan tata ruang yang lebih terperinci (RDTRK, RTBL), maupun rencana kegiatan sektoral seperti kawasan perdagangan, industri, permukiman, serta fasilitas umum dan sosial.

Arti penting RTRWK dalam konteks penyelenggaraan pembangunan perkotaan, menjadikan dalam penyusunannya harus mempertimbangkan beberapa faktor yang ikut mempengaruhi terhadap kualitas isi 
RTRWK itu sendiri. Diantara sekian banyak faktor, salah satu yang diasumsikan paling penting adalah perspektif atau paradigma yang digunakan dalam penyusunan RTRWK. Dalam penelitian ini, governance sebagai perspektif kontemporer dalam ranah administrasi publik digunakan sebagai pendekatan dalam penyusunan RTRWK melalui prinsip-prinsip yang menyertainya dalam konteks penyelenggaraan desentralisasi. Prinisp governance yang diteliti dalam kaitannya dengan penyusunan RTRWK adalah prinsip akuntabilitas, transparansi, responsif dan partisipasi. Selain itu, dari sudut pandang governance, peran para actor juga sangat penting di dalam pengambilan keputusan yang bekerja pada tingkat yang berbeda.

Diterapkannya prinsip governance dalam penyusunan tata ruang wilayah kota diharapkan akan menghasilkan produk rencana tata ruang yang tidak saja bersifat akomodatif dan legitimate. Akan tetapi juga diharapkan tidak menimbulkan persoalan dalam implementasinya dikemudian hari, karena keputusan yang dihasilkan tersebut merupakan kesepakatan bersama diantara para aktor dalam memanfaatkan ruang kota dalam kurun waktu 20 tahun mendatang.

\section{Prinsip Governance dengan Aktor Dalam Perencanaan Tata Ruang Kota}

Pemahaman responden terhadap governance terkait dengan perencanaan tata ruang kota selanjutnya mengantarkan kita pada analisis terhadap prinsip governance dengan aktor/ agensi yang terlibat dalam penyusunan RTRWK. Berdasarkan hasil penelitian diketahui, bahwa prioritas aktor/ agensi yang terlibat dalam penyusunan rencana tata ruang kota di wilayah studi dikaitkan dengan penerapan prinsip governance dan orientasi tujuan dalam rencana tata ruang kota dengan menggunakan analisis proses hirarki (AHP) dapat dipaparkan sebagai berikut.

Tabel 1.

Hasil Analisis gabungan Aktor/ Agensi Dalam Perencanaan Tata Ruang Kota dengan Prinsip Governance

\begin{tabular}{|l|c|c|c|c|}
\hline $\begin{array}{c}\text { Aktor/ } \\
\text { Agensi }\end{array}$ & $\begin{array}{c}\text { Peme- } \\
\text { rintah }\end{array}$ & $\begin{array}{c}\text { Masya } \\
\text { rakat }\end{array}$ & $\begin{array}{c}\text { Sw } \\
\text { asta }\end{array}$ & $\begin{array}{c}\text { Bobot } \\
\text { Prioritas }\end{array}$ \\
\hline $\begin{array}{l}\text { Prinsip } \\
\text { Gov }\end{array}$ & 1.096 & 1.168 & $\begin{array}{r}0.7 \\
36\end{array}$ & $\begin{array}{c}\text { Gabung } \\
\text { an }\end{array}$ \\
\hline $\begin{array}{l}\text { Akunta } \\
\text { bilitas }\end{array}$ & 1.160 & 0.713 & $\begin{array}{r}1.0 \\
38\end{array}$ & 2.867 \\
\hline $\begin{array}{l}\text { Transp } \\
\text { aransi }\end{array}$ & 1.116 & 0.920 & $\begin{array}{r}0.9 \\
67\end{array}$ & 3.009 \\
\hline $\begin{array}{l}\text { Respon } \\
\text { sif }\end{array}$ & 0.890 & 1.166 & $\begin{array}{r}0.9 \\
29\end{array}$ & 3.021 \\
\hline $\begin{array}{l}\text { Partisip } \\
\text { asi }\end{array}$ & 0.834 & 1.257 & $\begin{array}{r}1.0 \\
31\end{array}$ & $\mathbf{3 . 1 4 1}$ \\
\hline
\end{tabular}

Prioritas:
1. Partisipasi
$=3.141$
2. Responsibilitas
$=3.021$
3. Transparansi
$=3.009$
4. Akuntabilitas
$=2.867$

Data tabel diatas menunjukkan, bahwa bobot aktor dalam perencanaan tata ruang kota yang diutamakan adalah aktor masyarakat (civil society). Hal itu tercermin dari nilai bobot prioritasnya yang tertinggi, yaitu 1.168, yang diikuti oleh aktor pemerintah kota dengan bobot nilainya sebesar 1.096 dan terakhir adalah aktor swasta (sektor bisnis) dengan bobot nilanya sebesar 0.736 . Sedangkan prioritas prinsip governance dalam perencanaan tata ruang kota berdasarkan aktor pemerintah 
kota prioritasnya secara berurutan adalah prinsip akuntabilitas, transparansi, responsif dan partisipasi. Hal tersebut dicerminkan dari nilai prioritas masingmasing prinsip secara berurutan sebesar 1.160 untuk partisipasi, 1.116 untuk transparansi, 0.890 untuk responsif, dan 0.834 untuk partisipasi. Bagi aktor masyarakat, prioritas prinsip governance dalam perencanaan tata ruang kota prioritasnya secara berurutan adalah prinsip partisipasi dengan nilai prioritas sebesar 1.257, diikuti dengan prinsip responsif dengan nilai prioritas sebesar 1.166, kemudian prinsip transparansi dengan nilai sebesar 0.920 , dan terakhir adalah prinsip akuntabilitas dengan nilai sebesar 0.713. Selanjutnya untuk aktor swasta (sektor bisnis), prinsip governance dalam perencanaan tata ruang kota prioritasnya secara berurutan adalah prinsip akuntabilitas dengan nilai 1.038, diikuti dengan prinsip partisipasi dengan nilai 1.031 , prinsip transparansi dengan nilai 0.967 , dan terakhir adalah prinsip responsif dengan nilai prioritasnya sebesar 0.929. Atas dasar data tersebut selanjutnya diketahui, bahwa dari hasil bobot prioritas gabungan menunjukkan prinsip partisipasi merupakan prioritas utama dari prinsip governance yang terkait dengan aktor/ agensi dalam penyusunan rencana tata ruang kota, khususnya di wilayah Kota Metro, yang diikuti dengan prinsip responsif; transparansi; dan akuntabilitas. Adapun bobot prioritas aktor/ agensi yang terlibat dalam penyusunan rencana tata ruang kota secara berurutan adalah aktor masyarakat; pemerintah kota dan sektor swasta (bisnis).

Hal tersebut mengandung makna, bahwa prioritas utama prinsip governance yang harus diterapkan dalam penyusunan rencana tata ruang kota adalah partisipasi masyarakat dalam mewujudkan rencana tata ruang kota yang baik dan berkualitas. Sehingga, dalam penyusunan rencana tata ruang wilayah, tuntutan penerapan prinsipprinsip good governance terus diupayakan melalui peningkatan kepedulian dan peran masyarakat khususnya dalam penetapan fungsi, peran, serta pendekatan kebijakan dan strategi penataan ruang. Pada level terendah, penerapan prinsip-prinsip good governance ini dilakukan melalui pelibatan masyarakat dalam pengelolaan lingkungan di sekitar tempat tinggalnya. Di lokasi penelitian, masyarakat ikut berpartisipasi dalam bentuk pemberian informasi dan masukan dalam forum yang difasilitasi pemerintah kota terhadap arah pengembangan dan alokasi pemanfaatan ruang kota. Meskipun terkesan adanya "jarak" pengetahuan dan pemahaman antara konsultan perencana dengan warga masyarakat, paling tidak melalui forum tersebut dapat menampung berbagai aspirasi dan ekspektasi masyarakat tentang arah pengembangan kotanya untuk 20 tahun yang akan datang. Arti penting partisipasi sebagai prioritas utama dalam penerapan prinsip governance dalam persepsi para aktor, mengandung makna bahwa disamping memperbaiki kualitas rencana tata ruang, peran serta masyarakat dimaksudkan sebagai proses pembelajaran masyarakat dan pemerintah yang secara langsung dapat memperbaiki kapasitas mereka dalam mencapai kesepakatan. Tidak dipungkiri bahwa rencana tata ruang pada dasarnya merupakan kesepakatan berbagai stakeholders yang dilahirkan melalui serangkain dialog yang konstruktif dan berkelanjutan. Melalui proses dialog 
yang terus menerus sepanjang keseluruhan proses penataan ruang, maka akan terjadi proses pembelajaran bersama dan pemahaman bersama (mutual understanding) berbagai pihak tentang penataan ruang.

Dalam lingkup pemanfaatan ruang perkotaan, masyarakat dapat berada pada posisi yang berbeda-beda, antara lain sebagai pelaku utama pemanfaatan ruang, sebagai pihak yang terkena dampak kegiatan pemanfaatan ruang, sebagai pihak yang mempengaruhi kebijakan pemanfaatan ruang perkotaan, sebagai pihak yang mengawasi dan mengkontrol kebijakan pemanfaatan ruang perkotaan. Oleh sebab itu, masyarakat merupakan pelaku pembangunan yang memiliki peran terbesar dalam pemanfaatan ruang perkotaan. Masyarakat dapat bertindak secara individu atau kelompok. Pada kondisi yang lebih berkembang, masyarakat membentuk suatu forum yang menghimpun anggota masyarakat yang memiliki kepentingan yang sama, dimana mereka dapat mengambil keputusan, membahas permasalahan, dan berusaha mempengaruhi kebijakan pemerintah. Dengan demikian, untuk mencapai pelaksanaan pemanfaatan ruang perkotaan yang sesuai dengan RTRW, keterlibatan masyarakat harus dihidupkan dan pemahaman masyarakat akan manfaat jangka pendek, menengah dan panjang penataan ruang perkotan perlu ditingkatkan.

Berdasarkan hasil wawancara dengan beberapa informan, diketahui bahwa masyarakat dapat berperan dalam penataan ruang wilayah kota diantaranya adalah:
1. Membuka diri terhadap pembelajaran dari pihak luar, terutama yang terkait dengan RTRW, pemanfaatan ruang dan pengawasan pemanfaatan ruang.

2. Mampu mengidentifikasi persoalan lingkungannya sendiri, peluangpeluang, dan mengelola kawasan permukiman di lingkungan sekitarnya. Hal ini dilakukan melalui aktivitas gotong royong warga yang cukup menonjol dari masyarakat.

3. Mampu mengorganisasi diri dan mendukung pengembangan wadah lokal atau forum masyarakat sebagai tempat masyarakat mengambil sikap atau keputusan. Hal tersebut tercermin dari berbagai aktivitas kelompok masyarakat (Pokmas) yang terdapat pada beberapa lingkungan melalui pendampingan oleh aparat pemerintah kota maupun organisasi non pemerintah (LSM).

4. Melaksanakan dan mengawasi pemanfaatan ruang sesuai ketentuan yang berlaku. Hal ini biasanya dilakukan oleh masyarakat manakala ada aktivitas pembangunan yang akan dilakukan oleh pihak swasta yang mensyaratkan adanya persyaratan persetujuan dari warga sekitar dalam radius lokasi pembangunan yang direncanakan.

5. Berperan aktif dalam kegiatan pelibatan masyarakat, baik berupa pemberian masukan, pengajuan keberatan, penyelenggaraan konsultasi, penyusunan program bersama pemerintah, atau berpartisipasi dalam proses mediasi. Masyarakat secara rutin melakukannya pada saat 
diselenggarakan musyawarah rencana pembangunan (Musrenbang) sekaligus kegiatan bedah APBD pada setiap tahun di tiap-tiap kelurahan.

6. Senantiasa menjalin kerjasama dan komunikasi dengan pemerintah kota agar berbagai kebijakan publik yang disusun mampu mengakomodasi berbagai need assessment masyarakat dan tidak merugikan kepentingan masyarakat.

Selain daripada itu, menempatkan masyarakat (civil society) sebagai prioritas aktor dalam perencanaan tata ruang kota membawa kita pada implikasi desentralisasi dan demokratisasi, yaitu keikutsertaan masyarakat dalam penentuan keputusan-keputusan publik. Apa yang dimaksudkan disini adalah, bahwa hal tersebut semakin memberikan penekanan yang kuat pada aspek ini, karena hal ini merupakan inti dari reformasi yang kita cita-citakan yaitu timbulnya masyarakat sipil (civil society), masyarakat yang egaliter berdasarkan kesetaraan. Dengan demikian, masyarakat harus diberikan peranan yang cukup besar dalam penentuan "nasib"nya. Oleh karenanya, pendekatan perencanaan yang sentralistik dan top-down yang cenderung bersifat goverment driven harus segera direvisi menjadi pendekatan perencanaan yang lebih partisipatif dan mengedepankan demand masyarakat yang disebut sebagai community driven planning (lihat: Friedman, 1997; Witoelar, 2007; Anirban, 2006; Enserink \& Koppenjan, 2007). Isu yang paling aktual untuk saat ini adalah bagaimana upaya untuk mencapai kondisi di mana masyarakat sendirilah yang mendesain rencana yang diinginkan dan pemerintah adalah fasilitatornya. Dengan demikian, bahwa keterlibatan stakeholder dalam perencanaan mengalami pergeseran, dari for people sebagai sifat perencanaan social reform menjadi by people sebagai sifat perencanaan dalam social learning (Friedman, 1987; Dardak, 2006).

Pada saat yang bersamaan, paradigma dalam sistem perencanaan juga mengalami perubahan dari orientasi hanya sebagai bagian dari proses administratif untuk mencapai tujuan internal organisasi publik, menjadi berorientasi sebagai bagian penting dari proses pembuatan kebijakan dan alternatif tindakan untuk mencapai tujuan kolektif. Proses perencanaan dilaksanakan dengan memasukkan prinsip pemberdayaan; pemerataan; demokratik; desentralistik; transparan; akuntabel; responsif dan partisipatif. Dalam pelaksanaannya diperlukan keterlibatan seluruh unsur lembaga negara; lembaga pemerintah; dunia usaha dan masyarakat luas. Secara lebih jelas Munir (2002), mengemukakan tentang peregeseran paradigma dalam sistem pemerintahan dan perencanaan pada tabel berikut ini.

Tabel 2. Pergeseran Paradigma Sistem Pemerintahan dan Sistem Perencanaan

\begin{tabular}{|c|c|c|c|}
\hline No & Aspek & $\begin{array}{l}\text { Paradigma } \\
\text { Lama }\end{array}$ & $\begin{array}{c}\text { Paradigma } \\
\text { Baru }\end{array}$ \\
\hline 1 & Pemerintahan & $\begin{array}{l}\text { Otokratik } \\
\text { Monolitik } \\
\text { Sentralistik } \\
\text { Unilateral }\end{array}$ & $\begin{array}{l}\text { Demokratik } \\
\text { Pluralistik } \\
\text { Desentralistik } \\
\text { Interaksionis }\end{array}$ \\
\hline 2 & Perencanaan & $\begin{array}{l}\text { Orientasi } \\
\text { Internal } \\
\text { Top-Down } \\
\text { Proses } \\
\text { Administratif } \\
\text { Peran } \\
\text { Pemerintah }\end{array}$ & $\begin{array}{l}\text { Orientasi } \\
\text { Eksternal } \\
\text { Bottom-Up } \\
\text { Proses } \\
\text { Tindakan } \\
\text { Pemerintah } \\
\text { dan Publik }\end{array}$ \\
\hline
\end{tabular}

Sumber: Munir (2002) 
Adanya paradigma baru tersebut, apabila dikaitkan dengan pengertian peran serta masyarakat lebih mengarah pada proses mempengaruhi pengambilan keputusan dalam keseluruhan proses penataan ruang, maka tujuan utama peran serta masyarakat mencakup dua hal pokok:

1. Pertama, melahirkan output rencana yang lebih baik daripada dilakukan hanya melalui proses teknokratis, dan

2. Kedua, mendorong proses capacity building masyarakat dan pemerintah.

Output rencana tata ruang yang dihasilkan melalui proses partisipasi diharapkan dapat memperkecil derajat konflik antar berbagai stakeholders terutama pada tahap pemanfaatan dan pengendalian pemanfaatan ruang. Disamping itu, peran serta masyarakat dapat memberikan kontribusi agar menghasilkan rencana tata ruang yang lebih sensitif dan lebih mampu mengartikulasikan kebutuhan berbagai kelompok masyarakat yang beragam dengan tidak mengenyampingkan kearifan lokal. Disamping memperbaiki kualitas rencana tata ruang, peran serta masyarakat dimaksudkan sebagai proses pembelajaran masyarakat dan pemerintah yang secara langsung dapat memperbaiki kapasitas mereka dalam mencapai kesepakatan. Tidak dipungkiri bahwa rencana tata ruang pada dasarnya merupakan kesepakatan berbagai stakeholders yang dilahirkan melalui serangkaian dialog yang konstruktif dan berkelanjutan. Melalui proses dialog yang terus menerus sepanjang keseluruhan proses penataan ruang, maka akan terjadi proses pembelajaran bersama dan pemahaman bersama (mutual understanding) berbagai pihak tentang penataan ruang. Sehingga proses ini secara langsung akan berkontribusi terhadap proses pembinaan penataan ruang.

\section{Simpulan}

Penerapan prinsip governance dalam perencanaan tata ruang kota berdasarkan actor/ agensi yang terlibat prioritasnya adalah pertama: partisipasi (3.141); kedua: responsif (3.021); ketiga: transparansi (3.009); dan keempat: akuntabilitas (2.867), dengan bobot aktornya secara berurutan adalah masyarakat (1.168); pemerintah kota (1.096); dan sektor bisnis (swasta) dengan bobot (0.736). Dengan demikian, masyarakat merupakan prioritas atau aktor kunci dalam perencanaan tata ruang kota yang terkait dengan penerapan prinsip governance. Peran masyarakat dilakukan terhadap keseluruhan tahapan perencanaan tata ruang kota dalam bentuk pemberian data dan informasi, opini dan aspirasi, serta keberatan dan sanggahan terhadap konsep pengembangan wilayah kota. Sehingga keterlibatan masyarakat dalam proses kebijakan penataan ruang membawa dampak terhadap kualitas kebijakan yang dihasilkan agar memperoleh legitimasi yang didasarkan pada rasionalitas yang memadai. Dengan demikian keterlibatan masyarakat dalam perencanaan tata ruang kota lebih merupakan aksi para partisipan melalui tindakan saling pengertian, berargumentasi, dan perjanjian dalam struktur pembentukan opini dan kehendak. Hal tersebut dapat ditempuh melalui: (a) Peningkatan Kesadaran; (b) Advokasi Kebijakan; (c) Pengembangan Institusi; dan (d) Pengembangan Kapasitas. 
Adapun implikasi kebijakan dari hasil studi ini yang terkait dengan manajemen pembangunan perkotaan, adalah bahwa penerapan prinsip governance harus menjadi mindset para aparatur publik dan perencana dalam perencanaan teknis dari rencana tata ruang, seperti: perencanaan kawasan strategis perkotaan; rencana ruang terbuka hijau; rencana detail tata ruang dan sejenisnya maupun dalam penataan kawasan-kawasan yang berpotensi menimbulkan konflik antar aktor, seperti: permukiman kumuh; kawasan squater; lokasi PKL dsb. Selain itu, dibutuhkan insentif kebijakan bagi operasionalisasi partisipasi masyarakat dalam perencanaan tata ruang kota dalam bentuk peraturan daerah maupun peraturan walikota sebagai pedoman operasional yang bersifat lokal, mengingat manusia dan masyarakat perkotaan merupakan salah satu modal dasar pembangunan perkotaan yang paling utama.

\section{Daftar Pustaka}

Anwar, Affendi, 1994. Proses Pembentukan Sistem Kota-Kota Dan Analisis Ekonomi Kawasan Perkotaan. Pengantar Mata Kuliah Analisis Sistem Urban dan Regional. PS-PWD Program Pascasarjana IPB. Bogor

Bovaird, T. \& Loffler, E., 2003, "Evaluating the quality of public governance: indicators, models and methodologies", Jurnal International Review of Administrative Science, Vol.69 (2003), 313-328

Dardak, Hermanto, 2006, "Peran Penataan Ruang Dalam Mewujudkan Kota
Berkelanjutan di Indonesia”. Makalah pada Penyampaian "Penghargaan Pekerjaan Umum Bidang Penataan Ruang” Semarang, 2 Mei 2006

Enserink, Bert and Koppenjan, Joop, "Public participation in China: sustainable urbanization and governance", dalam Jurnal Management of Environmental Quality: An International Journal Vol. 18 No. 4 Tahun 2007

Enserink, Bert and Koppenjan, Joop, "Public participation in China: sustainable urbanization and governance", dalam Jurnal Management of Environmental Quality: An International Journal Vol. 18 No. 4 Tahun 2007

Hans Klijn, Erick and Koppenjan, Joop, "Governance Network Theory: Past, Present and Future", dalam Jurnal Policy and Politic Vol. 40 No. 4, 587-606 Tahun 2012

Friedman, J., 1987, Planning in The Public Domain, From Knowledge to Action, Princeton University Press, New Jersey

Kunarjo. 1994. Perencanaan dan Pembiayaan Pembangunan. Penerbit UI Press, Jakarta

Munir, Risfan. 2002, "Merencana di Tengah Jerat Hutang", dalam Winarso, 2002. Pemikiran dan Praktek Perencanaan dalam Era Transformasi di Indonesia. Departemen Teknik Planologi, ITB, Bandung 
Riyadi \& Bratakusumah, Deddy Supriady, 2003. Perencanaan Pembangunan Daerah-Strategi Menggali Potensi Dalam Mewujudkan Otonomi Daerah. PT. Gramedia Pustaka Utama, Jakarta

Pal, Anirban, 2006. "Scope for bottom-up planning in Kolkata: rethoric vs reality", Environment and Urbanization Vol. 18, No. 2, October 2006

Pratikno, 2005. "Dari Good Governance Menuju Just dan Democratic Governance". Makalah pada Seminar Nasional "Governance in Practices: Belajar Dari Pengalaman di Indonesia”, yang diselenggarakan oleh Panitia Dies Fisipol UGM Ke 49, 25 September 2004

Prijadi, Ruslan, 2001. "Manajemen Perkotaan Di Era Globalisasi-
Desentralisasi”, Dalam USAHAWAN NO. 02 TH XXXI Februari 2001

Purnomohadi, Ning. 2006. RTH sebagai Unsur Utama Tata Ruang Kota. Departemen Pekerjaan Umum-Ditjen Penataan Ruang. Jakarta

Saaty, Thomas L., 1990. The Analytical Hierarchy Process: Planning, Priority Setting, Resource Allocation. Pittsburgh: University of Pittsburgh Press

Syarif, Rustam, 2005. Makalah dalam Seminar: "Pengelolaan Kota yang Efektif melalui Pembangunan PSPU: Permasalahan, Kebijakan, Strategi, dan Kerangka Hukum" Jakarta, 7 Desember 2005

Witoelar, Rachmat, 2007. Makalah Dalam Rapat Kerja Nasional Badan Koordinasi Tata Ruang Nasional 2007, Batam, 2 Agustus 2007 